\title{
35. FISSION TRACK STUDIES OF BASALT FROM LEG 34
}

\author{
D. Macdougall, Geological Research Division, Scripps Institution of Oceanography \\ La Jolla, California
}

\section{SAMPLE DESCRIPTION}

Three glassy samples from Leg 34 were received for analysis. The first, labeled only "34-319A-hole cuttings," was retrieved from Core 7 after the second entry into the hole. Thus, it is possible that this sample came from anywhere in the basement, but probable that it came from close to the top (Bass, this volume). The sample is an angular glass fragment with a thin, reddishbrown palagonite coating over parts of its surface. The only glassy material recovered from Hole $319 \mathrm{~A}$ as an in situ selvage is from the base of a flow unit in Core 2. As described below, the uranium content of the glass sample labeled "hole cuttings" clearly differentiates it from this selvage. The second sample analyzed, 319A-2-1, 27$30 \mathrm{~cm}$, is from the above-mentioned selvage. The fragment received is approximately $1 \mathrm{~cm}$ thick, with an outer, predominantly glassy margin $(\sim 2 \mathrm{~mm}$ in thickness, but variable) grading into rock with variolitic texture. The glass is coated with a thin $(\sim 300 \mu \mathrm{m})$ palagonite layer. The third sample analyzed, 320B-3-1, 101-105 cm, is a centimeter-sized glassy fragment partly coated with thin, reddish-brown palagonite. No gradation to variolitic texture is present in this sample.

\section{URANIUM CONCENTRATIONS}

Measured uranium concentrations are given in Table 1. All measurements were made using the induced fission track method (Price and Walker, 1963). Errors quoted are statistical counting errors and do not include possible errors (estimated to be $\leq 6 \%$ ) in the uranium content of the standard, a glass containing $0.35 \mathrm{ppm}$ uranium. Mica was used as the detector for induced tracks. Because of the low uranium concentrations of these samples, it was difficult to avoid averaging over microlites and microphenocrysts in the measurements of uranium in glassy regions. Thus the values listed for "glass" may refer to material containing up to approximately $10 \%$ crystallites.

The uranium contents of all samples measured are lower than for "average" tholeiitic basalts, which generally contain about $0.1 \mathrm{ppm}$ (e.g., Tatsumoto et al.,

TABLE 1

Uranium Concentrations in Some Leg 34 Basalts

\begin{tabular}{lc}
\hline Sample & Uranium (ppm) \\
\hline $319 \mathrm{~A}-$ "hole cuttings" (glass) & $0.042 \pm 0.002$ \\
$319 \mathrm{~A}-2-1,27-30$ (glass) & $0.016 \pm 0.002$ \\
$\quad$ (variolitic) & $0.015 \pm 0.002$ \\
$320 \mathrm{~B}-3-1,101-105$ (glass) & $0.051 \pm 0.002$ \\
\hline
\end{tabular}

1965). The in situ selvage from Core 2 at Site 319A is particularly striking in this regard, being a factor of six lower than the "average." This basalt would appear to be little fractionated, although evidence from other elements is required to bear this out. Unfortunately, the relationship of this sample to the glassy fragment recovered from Core 7 and labeled "hole cuttings" is unknown. The uranium content of the latter is approximately three times as great as that of the sample from Core 2 and must be from a separate flow.

\section{SPONTANEOUS FISSION TRACKS}

Fission track dating is difficult if samples have spontaneous track densities in the range of one hundred to a few hundred tracks per $\mathrm{cm}^{2}$, and becomes impractical at levels much below 100 tracks $\mathrm{cm}^{-2}$. Based on the uranium concentrations in Table 1, and the basal sediment ages at Sites 319 and $320(\sim 15$ m.y. and 30 m.y., respectively), the expected spontaneous track densities are $\sim 100 \mathrm{~cm}^{-2}, \sim 35 \mathrm{~cm}^{-2}$, and $\sim 230 \mathrm{~cm}^{-2}$ for the three samples in Table 1. Hence these glasses would be inherently difficult to date by this method, and exhaustive studies were not undertaken. However, in order to get a rough measure of the actual spontaneous track densities, polished glassy samples were etched, and selected areas, totaling $\sim 5 \mathrm{~mm}^{2}$ for each sample, were scanned for tracks at $800 \times$. No tracks were observed for the "hole cuttings" sample from 319A or for the 320B sample, indicating a density $<20$ tracks $/ \mathrm{cm}^{2}$ in each case. This is clearly less than the expected values. These glasses may have undergone annealing as postulated for other DSDP samples (Macdougall, 1973). For Sample 319A-2-1, 27-30 cm, one spontaneous track was observed in $5 \mathrm{~mm}^{2}$, giving a track density of 20 tracks $/ \mathrm{cm}^{2}$. Within the statistics (!) of a single event, this is identical to the predicted 34 tracks $/ \mathrm{cm}^{2}$ for $15 \mathrm{~m} . \mathrm{y}$., and thus compatible with the paleontologic age of the sediments overlying the basalt at this site. The difference between this and the "hole cuttings" sample remains unexplained.

\section{REFERENCES}

Macdougall, D., 1973. Fission track dating of oceanic basalts: Am. Geophys. Union Trans., v. 54, p. 987-988.

Price, P.B. and Walker, R.M., 1963. A simple method of measuring low uranium concentrations in natural crystals: Appl. Phys. Lett., v. 2, p. 23-25.

Tatsumoto, M., Hedge, C.E., and Engel, A.E.J., 1965. Potassium, rubidium, strontium, thorium, uranium and the ratio of strontium-87 to strontium-86 in oceanic tholeitic basalt: Science, v. 50, p. 886-888. 